\title{
Evaluation of Botanicals against Fusarium solani (Mart.) Sacc. Inciting Root Rot Disease of Bael (Aegle marmelos Correa)
}

\author{
Manjeet Singh $^{1 *}$, Sushil Sharma ${ }^{2}$ and Rajendra Nasnwa ${ }^{3}$ \\ ${ }^{1}$ Department of Plant Pathology, Chaudhary Charan Singh Haryana Agricultural University, \\ Hisar, Haryana, India \\ ${ }^{2}$ School of Agriculture, Suresh Gyan Vihar University, Jaipur, Rajasthan, India \\ ${ }^{3}$ Department of Plant Pathology, SKRAU, Bikaner, Rajasthan, India \\ *Corresponding author
}

\section{A B S T R A C T}

\section{Keywords \\ Antifungal, Botanicals, Fusarium solani, Root rot, Bael \\ Article Info \\ Accepted: \\ 10 April 2018 \\ Available Online: \\ 10 May 2018}

\begin{abstract}
Nine botanicals were evaluated for their antifungal activity against Fusarium solani causing root rot disease in Bael by employing poisoned food technique under laboratory conditions. The results indicated that all the botanicals inhibited the growth of the Fusarium solani as compared to control. Out of nine botanical tested, turmeric rhizome extract was found most effective as it showed minimum mycelial growth $(33.3 \mathrm{~mm}, 20.7$ $\mathrm{mm}$ and $13.5 \mathrm{~mm})$ and maximum mycelial growth inhibition $(63.1 \%, 77.0 \%$ and $85.1 \%)$ followed by neem, onion, tulsi, aonla, aak, datura and jamun at 5, 10 and 20 per cent concentrations, respectively. Congress grass recorded as least effective botanical against the pathogen at all the three concentrations.
\end{abstract}

\section{Introduction}

Bael (Aegle marmelos Correa) is an important and popular indigenous fruit tree of India. It is grown in various parts of South East Asia including India, Pakistan, Bangladesh, Sri Lanka, Myanmar, Thailand and most of the South-East Asian countries. In India, Bael is being grown throughout the country, it is also known by other vernacular names like Bael, sriphal, bili, belo, bilva and Bengal quince (John and Stevenson, 1979). According to Hindu customs, the leaves of Bael tree are considered sacred and offered to the Lord Shiva. Its medicinal properties have been dealt with in the 'Charaka Samhita', an early medical treatise in Sanskrit (Aiyer, 1956). The importance of Bael fruit lies in its curative properties, which make the Bael tree one of the most useful medicinal plants of India (Kirtikar and Basu, 1935).

Though, there are scattered reports on its fruit and foliar diseases, however, heavy decline in Bael due to Fusarium solani (Mart.) Sacc. have been recorded in different parts of the India especially in Haryana and Rajasthan (Anonymous, 2011; Sharma and Gaur, 2014). Root rot of Bael has become a potential threat since 2007 in Haryana. The use of synthetic 
fungicides for the management of disease is not only hazardous for human beings but also increases different types of environmental pollution and toxicological problems. Botanicals have assumed special significance for plant disease management in present day strategy being ecologically safe. The popularity of botanical pesticides is increasing and some plant products are being used globally as green pesticides (Gurjar et al., 2012). Several botanicals have been demonstrated to possess excellent fungicidal properties (Bhardwaj, 2012). Inhibition of plant pathogenic fungi by many antifungal compounds of plant origin led to the present study to explore the feasibility of using extract of several plants for the management of Fusarium solani causing root rot disease of Bael under in vitro conditions.

\section{Materials and Methods}

To estimate the antimytotic behaviour of different botanicals against Fusarium solani, extracts of nine plant species viz., aak (Quercus robur), aonla (Endlica phyllanthus), congress grass (Parthenium hysterophorus), datura (Datura stramonium), jamun (Syzygium cumini), neem (Azadirachta indica), onion (Allium cepa), tulsi (Octimum sanctum) and turmeric (Curcuma longa) (Table 1) were evaluated. Leaf extracts of all plant species except onion bulb and turmeric rhizomes were taken and evaluated in vitro for their antifungal activity against $F$. solani by using poisoned food technique.

The extracts were prepared by crushing $100 \mathrm{~g}$ green leaves (except rhizome in turmeric and bulb in onion) of each plant species in $100 \mathrm{ml}$ sterilized distilled water using mixer and grinder. The supernatant was filtered through double layered muslin cloth followed by Whatman filter paper no. 1. The filtrates were then centrifuged at $7000 \mathrm{rpm}$ for ten minutes. The clear supernatants thus obtained were kept in refrigerator at $5^{0} \mathrm{C}$, and were used in further experiment. Three concentrations i.e. 5, 10 and 20 per cent of the stock solution were prepared.

The stock solution (100\%) was further diluted with the help of double sterilized distilled water to give concentrations of 5, 10 and 20 per cent. Double strength PDA was also prepared and sterilized in autoclave for 20 minutes at $15 \mathrm{lbs}$ inch $^{-2}$ pressure. This medium was taken in flask at the rate of $50 \mathrm{ml}$ per flask and diluted with equal amount of extract solution to give 5, 10 and 20 per cent concentrations of each plants extract. The PDA medium containing required dose of extract was poured in sterilized petri plates with four replications of each concentration and was kept for solidification. All the plates containing phytoextracts were inoculated by placing $5 \mathrm{~mm}$ mycelial disc of actively growing culture of Fusarium solani (10 days old) grown on PDA in each petriplates and inoculated plates were incubated at $27 \pm 2^{\circ} \mathrm{C}$ in BOD incubator. Control plates containing PDA medium and inoculated with Fusarium solani were also kept for comparison.

Experiment was conducted with complete randomized design. Radial growth of the $F$. solani both in treatment as well as control plates were recorded and per cent growth inhibition of $F$. solani at different concentrations was calculated on the basis of decrease in area of mycelial growth with respect to check by using the formula given by Vincent (1947) as described below.

$$
\mathrm{I}(\%)=\frac{\mathrm{C}-\mathrm{T}}{\mathrm{C}}
$$

Where,

$\mathrm{I}=$ Per cent inhibition

$\mathrm{C}=$ Radial growth of colony in control $(\mathrm{mm})$ 
$\mathrm{T}=$ Radial growth of colony in treatment (mm)

\section{Results and Discussion}

Efficacy of nine botanicals having antifungal activity was evaluated (Table 2 and 3; Fig. 1 and 2) in vitro by poisoned food technique against Fusarium solani inciting root rot disease of Bael. The results present in Table 2 and Figure 1 revealed that the mycelial growth of the $F$. solani was significantly reduced by all the botanicals.

Among the botanicals, Significantly lowest mycelial growth was recorded in turmeric rhizomes extract $(33.25,20.70$ and $13.45 \mathrm{~mm})$ followed by neem leaves extract $(37.75,27.13$ and $19.80 \mathrm{~mm}$ ) over control at 5, 10 and 20 per cent concentrations respectively and these both were significantly superior over the rest. The next best in order of merit was onion bulbs extract (41.30, 31.17 and $24.50 \mathrm{~mm})$, tulsi leaves extract $(45.25,35.40$ and 28.60 $\mathrm{mm})$, aonla leaves extract $(51.20,39.75$ and $32.17 \mathrm{~mm}$ ), aak leaves extract $(55.55,47.15$, $38.44 \mathrm{~mm})$, datura leaves extract $(62.00,56.25$ and $50.30 \mathrm{~mm}$ ) and jamun leaves extract (73.33, 64.50 and $57.50 \mathrm{~mm}$ ) and congress grass extract (77.50, 74.75 and $67.67 \mathrm{~mm}$ ) was found least effective and showed maximum mycelial growth at all the concentrations.

All the botanicals were found significantly effective in inhibiting the mycelial growth (Table 3 and Fig. 2). Significantly highest mycelial growth inhibition was recorded in turmeric rhizomes extract $(63.06,77.00$ and $85.06 \%)$ followed by neem leaves extract $(58.06,69.86$ and $78.00 \%)$ and congress grass extract $(13.89,16.94$ and $24.81 \%)$ was found least effective in inhibiting the mycelial growth of $F$. solani over control at 5, 10 and 20 per cent concentrations respectively.

Fig.1 Mycelial growth of Fusarium solani by plant extracts at different concentrations

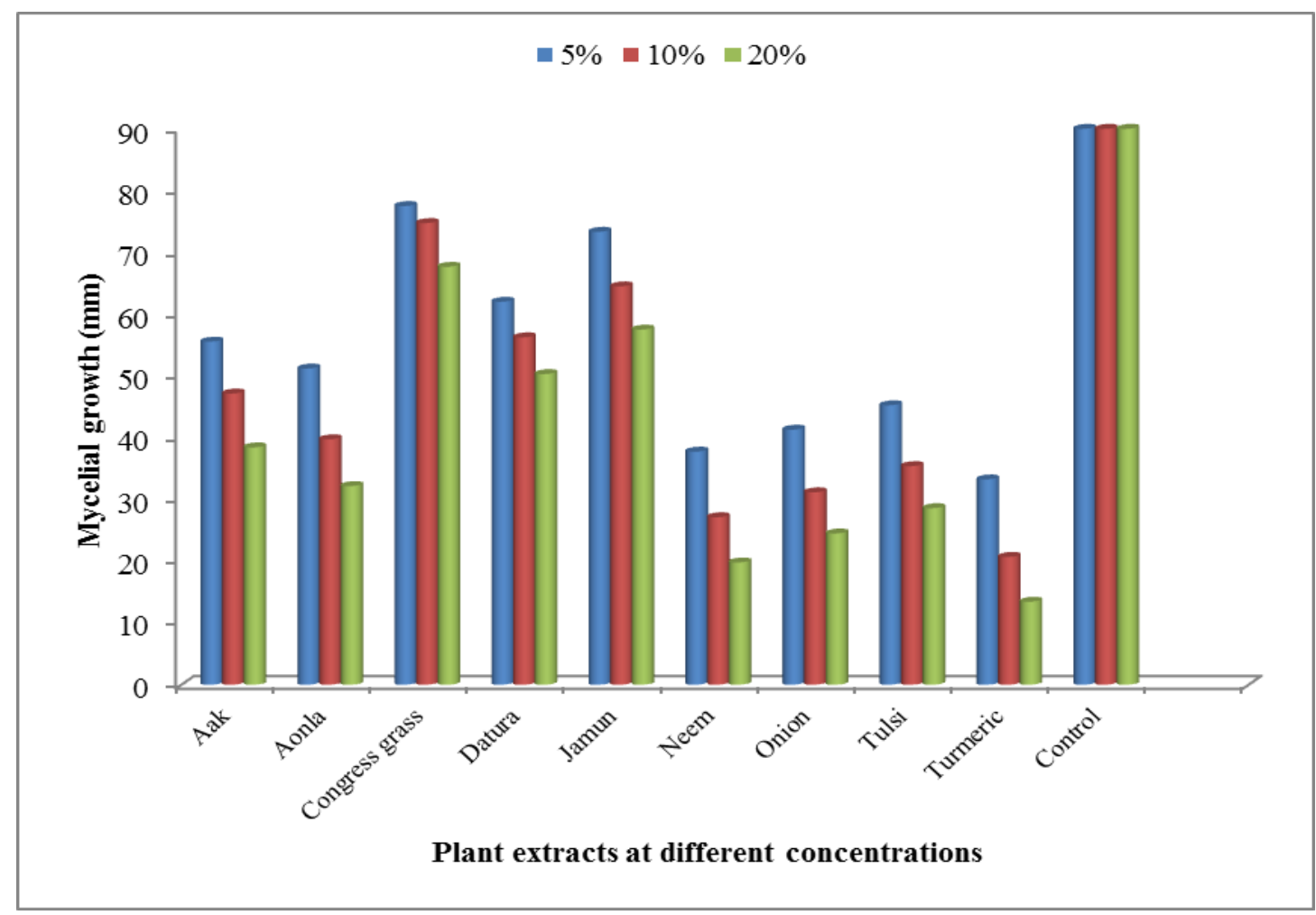


Fig.2 Mycelial growth inhibition of Fusarium solani by plant extracts at different concentrations

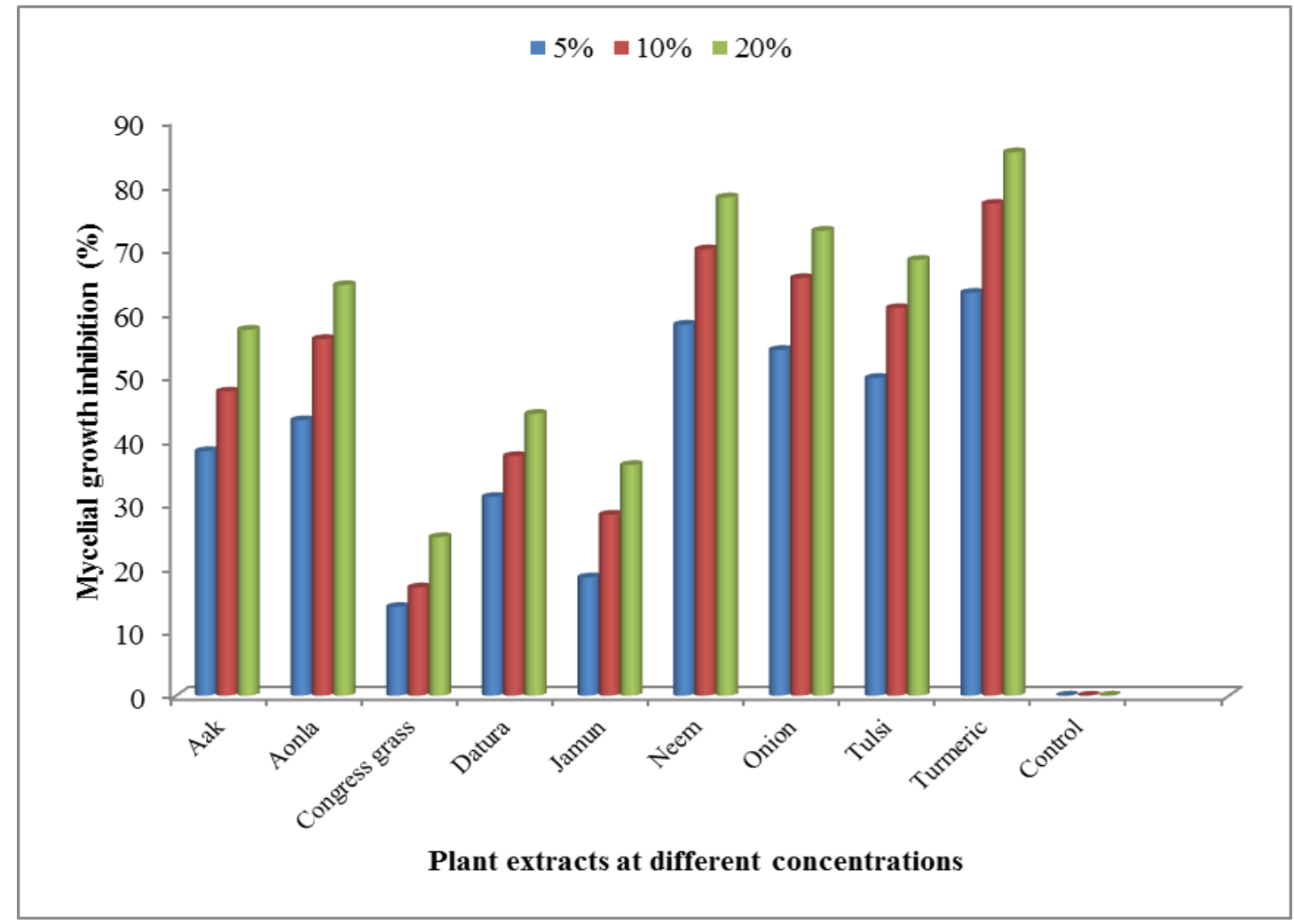

Table.1 List of different botanicals and their parts with different concentrations against F. solani causing root rot of Bael

\begin{tabular}{|c|l|l|c|c|c|c|}
\hline Sr. No. & Common name & \multicolumn{1}{|c|}{ Botanical name } & Plant part & \multicolumn{3}{|c|}{ Concentrations $(\%)$} \\
\hline $\mathbf{1}$ & Aak & Quercus robur & Leaves & 5 & 10 & 20 \\
\hline $\mathbf{2}$ & Aonla & Endlica phyllanthus & Leaves & 5 & 10 & 20 \\
\hline $\mathbf{3}$ & Congress grass & Parthenium hysterophorus & Leaves & 5 & 10 & 20 \\
\hline $\mathbf{4}$ & Datura & Datura stramonium & Leaves & 5 & 10 & 20 \\
\hline $\mathbf{5}$ & Jamun & Syzygium cumini & Leaves & 5 & 10 & 20 \\
\hline $\mathbf{6}$ & Neem & Azadirachta indica & Leaves & 5 & 10 & 20 \\
\hline $\mathbf{7}$ & Onion & Allium cepa & Bulbs & 5 & 10 & 20 \\
\hline $\mathbf{8}$ & Tulsi & Octimum sanctum & Leaves & 5 & 10 & 20 \\
\hline $\mathbf{9}$ & Turmeric & Curcuma longa) & Rhizomes & 5 & 10 & 20 \\
\hline $\mathbf{1 0}$ & Control* & - & - & - & - & - \\
\hline
\end{tabular}

*Devoid of botanical 
Table.2 Effect of different botanicals on the mycelial growth of Fusarium solani under in vitro conditions

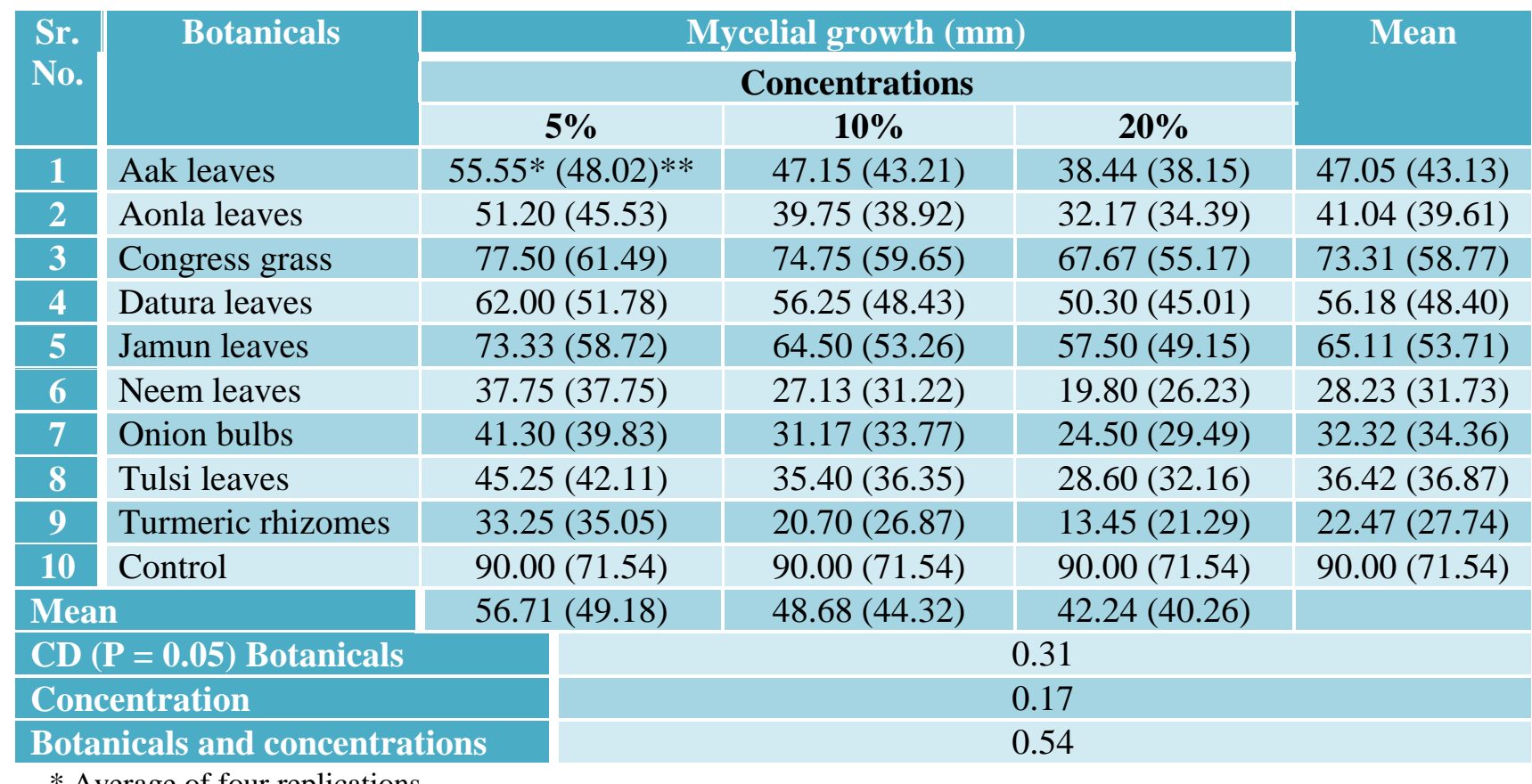

* Average of four replications

**Figures in parentheses are angular transformed values

Table.3 Effect of different botanicals on the inhibition of mycelial growth of $F$. solani under in vitro conditions

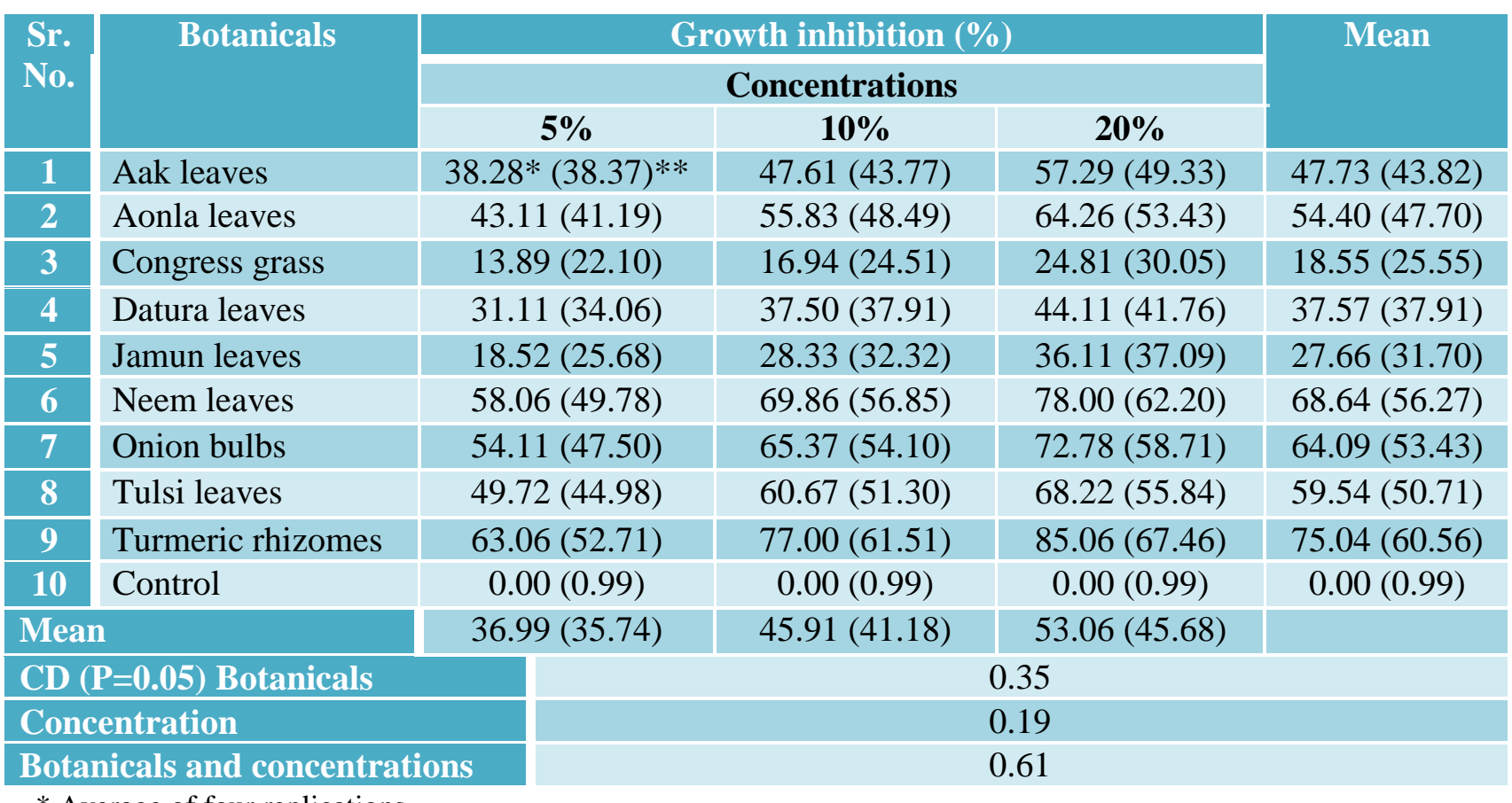

* Average of four replications

**Figures in parentheses are angular transformed values 
Onion bulbs extract (54.11, 65.37 and 72.78 $\%$ ), tulsi leaves extract $(49.72,60.67$ and $68.22 \%)$, aonla leaves extract $(43.11,55.83$ and $64.26 \%$ ), aak leaves extract $(38.28,47.61$ and $57.29 \%$ ), datura leaves extract (31.11, 37.50 and $44.11 \%$ ) and jamun leaves extract $(18.52,28.33$ and $36.11 \%)$ were rated next to turmeric rhizome extract and neem leaves extract in descending order.

These findings of present investigation are in favour of work done by Patel et al., (2010). They have reported mycelia growth inhibition of Fusarium solani by using turmeric rhizomes extract. Kapadiya et al., 2014 also observed that maximum mean inhibition in turmeric rhizome extract followed by jatropha leaf extract and neem leaves extract.

The turmeric and garlic extracts were most effective in inhibiting the growth of Fusarium spp. (Patel and Vala, 2004; Assadi and Behroozin, 1987). Philip and Sharma, 1997; Mamatha and Ravishankar (2004); Joseph et al., (2008); Obongoya (2010) also reported that neem leaf extract was effective in mycelia growth inhibition of $F$. solani. Garlic clove extract and neem leaf extract were most effective for the growth inhibition of $F$. solani (Mallesh et al., (2009).

Further, it can be concluded that the efficacy of botanicals differed significantly in inhibiting the radial growth of the test fungus at all the three concentrations $(5,10$ and $20 \%$ ). The higher concentration of all the botanicals offered significantly higher per cent mycelial growth inhibition as compared to their lower levels. Among the different botanicals, turmeric rhizome extract had significant antifungal properties against root rot pathogen of Bael followed by neem leaves and onion bulbs extracts. These botanicals could be further subjected to field trials to access their effectiveness under field conditions.

\section{References}

Aiyer, A.K.Y.U., 1956. The Antiquity of Some Field and Forest Flora of India. Bangalore Printing and Publishing Co. Ltd., Bangalore.

Anonymous, 2011. Annual Report of AICRP on Arid Zone Fruits. CIAH, Bikaner, Rajasthan.

Assadi, P. and Behroozin, M., 1987.The effect of bulb extract of onion and garlic on the mycelial growth of Fusarium spp. and Sclerotium ceptorium. Iranian Journal of Plant Pathology, 23(1-4): 2935.

Bhardwaj, S.K., 2012. Evaluation of plant extracts as antifungal agents against Fusarium solani (Mart.) Sacc. World Journal of Agricultural Sciences, 8(4): 385-388.

Gurjar, M.S., Ali, S., Akhtar, M. and Singh, K.M., 2012. Efficacy of plant extracts in plant disease management. Agricultural Sciences, 3(3): 425-433.

John, L. and Stevenson, V., 1979. The Complete Book of Fruit. Anqus and Roberson Publications.

Joseph, B., Muzafar, A. D. and Kumar, V. 2008. Bioefficacy of plant extracts to control Fusarium solani f. sp. Melongenae incitant of brinjal wilt. Global Journal of Biotechnology \& Biochemistry, 3(2): 56-59.

Kapadiya, I.B., Undhad S.V., Talaviya J.R. and Siddhapara M.R., 2014. Evaluation of phytoextracts against Fusarium solani causing root rot of okra. JBiopest, 7: 7-9.

Kirtikar, K.R and Basu, B.D., 1935. Indian Medicinal Plants. Vol. 1. Published by L.M. Basu, Allahabad.

Mallesh, S. B., Narendrappa, T. and Kumari, 2009. Management of root rot of sage (Salvia officinallis) caused by Fusarium solani and Rhizoctonia solani. 
International Journal of Plant Patel, N.N. and Vala, D.G., 2004. Studies on Protection, 2(2): 261-264. wilt (Fusarium solani) of okra under south Gujarat condition. Plant Disease Research, 19 (2): 204.

Evaluation of fungicides and plant extract against Fusarium solani leaf blight in Terminalia catappa. Journal of Mycology and Plant Pathology, 34(2): 306-307.

Obongoya, B. O., Wagai, S. O. and Odhiambo, G., 2010. Phytotoxic effect of selected crude plant extracts on soil borne Fungi of common bean, African Journal of Crop Sciences, 18(1): 15-22.

Patel, N. N., Joshi, K. R., Patel, P. M., Patel, M. R. and Patel, M. R. 2010. Bioefficacy of plant extracts against Fusarium solani. International Journal of Plant Protection, 3 (2): 306-308.

Philip, T. and Sharma, D.D., 1997. In vitro evalution of leaf and oil cake extract of Azadirachta indica and Pongamia glabra on mulberry root rot pathogen. Indian Journal of Sericulture, 36 (2): 150-152.

Sharma, S. and Gaur, R.K., 2014. Occurrence of root rot in Aegle marmelos - a new host record. The Indian Forester, 140: 203-204.

Vincent, J.M., 1947. Distortion of fungal hyphae in the presence of certain inhibitors. Nature, 159: 850.

\section{How to cite this article:}

Manjeet Singh, Sushil Sharma and Rajendra Nasnwa. 2018. Evaluation of Botanicals against Fusarium solani (Mart.) Sacc. Inciting Root Rot Disease of Bael (Aegle marmelos Correa). Int.J.Curr.Microbiol.App.Sci. 7(05): 970-976. doi: https://doi.org/10.20546/ijcmas.2018.705.120 